Received: 2019-08-01

\title{
Fireweed (Epilobium angustifolium L.): botany, phytochemistry and traditional uses. A review
}

\author{
ARTUR ADAMCZAK ${ }^{1 *}$, MARIOLA DREGER ${ }^{2}$, KATARZYNA SEIDLER-ŁOŻYKOWSKA ${ }^{1}$, \\ KAROLINA WIELGUS ${ }^{2}$
}

\author{
${ }^{1}$ Department of Botany, Breeding and Agricultural Technology of Medicinal Plants \\ Institute of Natural Fibres and Medicinal Plants \\ Kolejowa 2 \\ 62-064 Plewiska, Poland \\ ${ }^{2}$ Department of Biotechnology \\ Institute of Natural Fibres and Medicinal Plants \\ Wojska Polskiego 71B \\ 60-630 Poznań, Poland \\ *corresponding author: phone: +48 (61) 665-95-50, e-mail: artur.adamczak@iwnirz.pl
}

\section{Summary}

Fireweed (Epilobium angustifolium L., Onagraceae) is one of important medicinal plants used especially in the treatment of urogenital disorders, including benign prostatic hyperplasia (BPH) and prostatitis. The therapeutic effects of E. angustifolium extracts comprise antiproliferative, anti-inflammatory, immunomodulatory, antioxidant, and also antimicrobial activities. The aim of the present review was to provide the information on the botany, phytochemistry and traditional uses of E. angustifolium. This plant is a widespread circumboreal species of North America and Eurasia, tolerant in terms of habitat conditions, and often occupying man-made open habitats. Phytochemical studies on E. angustifolium resulted in the identification of about 250 different metabolites, including about 170 substances found for the first time in this plant in the last six years (2014-2019). Fireweed has an abundance of polyphenolic compounds, particularly ellagitannins. Oenothein B and quercetin-3-O-glucuronide are proposed as markers for the identification and standardization of the plant raw material. E. angustifolium exhibits significant phytochemical variability in relation to the geographical origin, plant part and time of harvest/vegetation phase. Survey of the ethnobotanical literature showed that the above-mentioned species has been widely used not only as a medicinal, but also as an edible, honey and decorative plant. 
Key words: rosebay willowherb, phytochemical composition and variability, ellagitannins, oenothein B, ethnobotany

Słowa kluczowe: wierzbówka kiprzyca, skład i zmienność fitochemiczna, elagotaniny, oenoteina B, etnobotanika

\section{INTRODUCTION}

Nowadays, the consumption of herbal products and the popularity of dietary supplements are growing throughout the world. Nutraceuticals or functional foods are intended to improve the state of health and well-being and to reduce the risk of nutrition-associated diseases, including cancer prevention. Fireweed (Epilobium angustifolium L.) is an important medicinal plant used in the pharmaceutical, food and cosmetic industries. It is particularly utilized in the treatment of benign prostatic hyperplasia (BPH) and prostatitis [1]. Today, dietary supplements or nutraceuticals containing E. angustifolium components are widely available in many countries in the form of tea, capsules, pills, water and alcohol extracts/tonics. Fireweed extracts are also utilized in creams, shampoos and other cosmetic products, especially for acne.

E. angustifolium is a rich source of phenolic compounds, especially hydrolysable tannins (ellagitannins), flavonoids, and phenolic acids [2-4]. Medicinal properties of fireweed extracts have been attributed to the synergic effect of polyphenols and the presence of the most abundant, compound - oenothein B. This substance shows various pharmacological activities, including anti-androgenic, antiproliferative, anticancer, antioxidant, anti-inflammatory, and immunomodulatory properties [5-10]. Additionally, E. angustifolium exhibits antimicrobial [1115], analgesic [16] as well as photoprotective and antiaging [17] activities.

Recently, the number of publications concerning the above-mentioned species has increased significantly. Screening of the Scopus database with the keywords of 'Epilobium/Chamerion/Chamaenerion angustifolium' found 416 document results, including 80 articles published in the years of 2014-2019. A new detailed summary is required not only for phytochemistry and pharmacology of E. angustifolium, but also in the case of scattered data on fireweed botany and ethnobotany.

The aim of the study was to provide an overview of information available on the botany, phytochemistry and traditional uses of E. angustifolium. In the botanical part, we described taxonomy, synonyms, and also morphology, ploidy, distribution and habitats of fireweed. The phytochemistry included the composition of the bioactive substances found in the plant raw material, with particular emphasis on the newly identified metabolites and with the description of the phytochemical variability of this species. In turn, the ethnobotanical characteristic aimed to present the traditional uses of E. angustifolium as a medicinal, edible, honey and decorative plant.

\section{BOTANY}

\section{Taxonomy}

Epilobium (Chamerion) angustifolium is classified to the Onagraceae family, which consists of 22 genera and approximately 650 species. The genus Chamerion (Raf.) Raf. ex Holub (syn. Chamaenerion Ség.) with eight species restricted to the northern hemisphere (mainly in Eurasia) belongs to the Onagroideae subfamily and Epilobieae tribe [18]. Relatively often, it is included in Epilobium L., which is the largest genus in the Onagraceae [19-22]. However, Chamerion clearly differs from Epilobium in terms of flower structure, leaf arrangement and other features [18, 23-25]. Molecular data also show that Chamerion is a separate monophyletic group of plants [26-28].

\section{Synonyms}

The Plant List [22] provides more than 40 synonyms of the species described, with three of these being the most commonly used: Epilobium angustifolium L., Chamerion angustifolium (L.) Holub and Chamaenerion angustifolium (L.) Scop. According to Holub [23], Chamerion should be considered the correct Latin name of this genus, while Chamaenerion is an illegitimate name. On the other hand, Sennikov [25] recently presented arguments for the restoration of the older name Chamaenerion. However, in 
this review, the name appearing most frequently in the references will be used: Epilobium angustifolium.

E. angustifolium is commonly known as fireweed in the United States and rosebay willowherb in Britain [25]. Other names mentioned include: perennial fireweed, narrow-leaved fireweed, great willowherb, willow herb, flowering willow, French willow, etc. $[29,30]$.

\section{Morphology and ploidy}

Fireweed is an herbaceous perennial with long branched rhizomes and fleshy stolons. Green stems, frequently reddish, glabrous below and pubescent above, are erect up to $2 \mathrm{~m}$ high. The willow-like leaves are alternate, 3-20 cm long. E. angustifolium blooms from June to September, developing large raceme inflorescences consist of a number of pink (rarely white) flowers (figure 1). They are up to $3 \mathrm{~cm}$ in diameter, zygomorphic, epigynous with a small nectar-secreting disc, markedly protandrous. The capsules, $4-8 \mathrm{~cm}$ long, contain small light brown seeds (1.0-1.3 mm in length) with greyish white hairs up to $13 \mathrm{~mm}$ long. One plant could produce 76000 wind-dispersed seeds per year [31-33]. The weight of 1000 seeds is about $0.07 \mathrm{~g}$ [34] and without the pappus reaches about $0.05 \mathrm{~g}$ [35].

E. angustifolium is a variable species diverse in terms of morphology and ploidy. The diploid representing subsp. angustifolium $(\mathrm{n}=18)$ has subsessile leaves with an obtuse or subrounded base, subentire margin, and glabrous abaxial midribs, as well as subglabrous stems and usually triporate pollen. The polyploid plants of subsp. circumvagum $(n=36,54)$ are generally luxuriant with taller stems, larger leaves, flowers and pollen. They have leaves with petioles $2-7 \mathrm{~mm}$ long, a cuneate base, denticulate margin, glabrous to very pubescent midribs, as well as strigillose stems, at least in the upper section, while pollen is usually a mixture of triporate and quadriporate grains $[36,37$.

\section{Distribution and habitats}

E. angustifolium is a widespread circumboreal species occurring in the temperate zone of North America and Eurasia at a latitude from $25^{\circ}$ to $70^{\circ}$ north. It grows both in the lowlands and in the mountains: in Switzerland to $2530 \mathrm{~m}$, in North America to $3960 \mathrm{~m}$, and in the Himalayas to an altitude of $4850 \mathrm{~m}$ a.s.l. Diploid populations occur in colder climates: in Greenland, Canada, Alaska, Siberia and northern Europe, and also tend to develop at higher altitudes. Tetraploids grow in warmer and drier habitats occupying the southern part of the range in Eurasia and North America $[18,38,39]$. In turn, triploids $(\mathrm{n}=27)$ appear in mixed-ploidy populations of border areas [40]. The hexaploid cytotype was reported only in central Japan and the Yunnan province of China $[36,41]$.

Fireweed is a common plant occupying manmade open habitats, such as deforested or burned

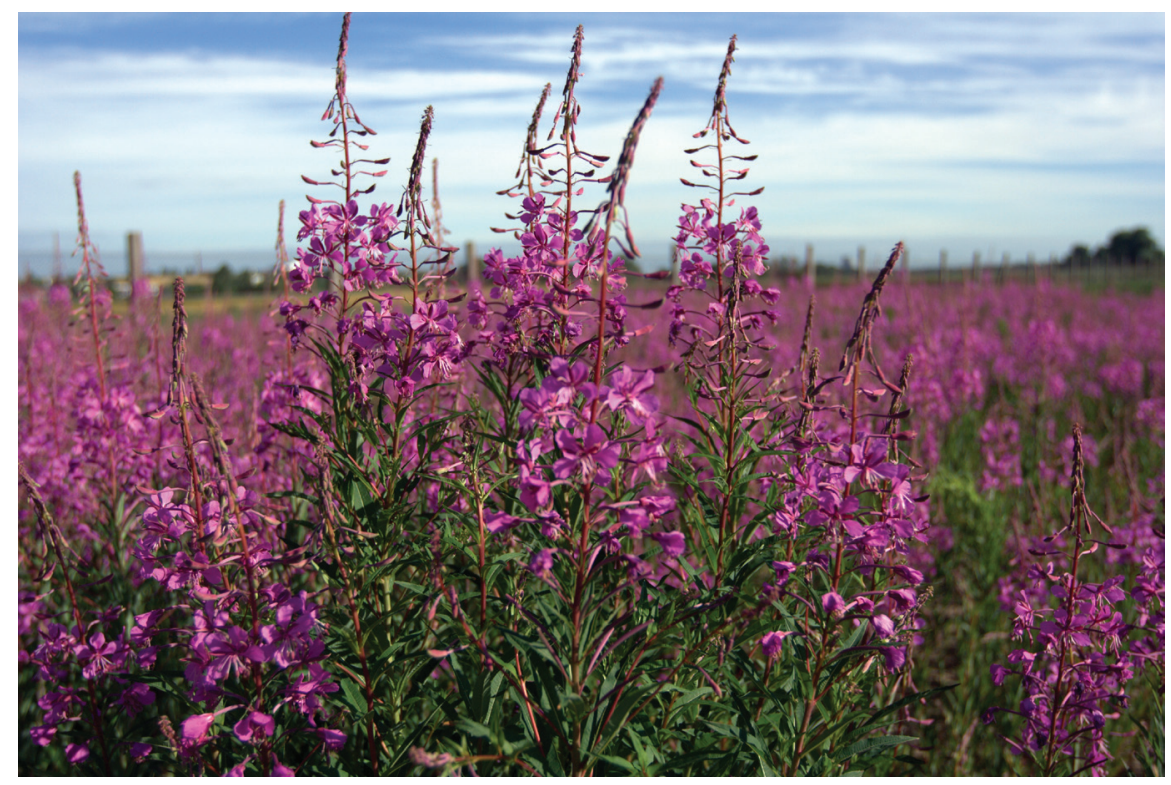

Figure 1

Epilobium angustifolium in the blooming phase (Krajewice, Poland) 
areas, roadsides and railway embankments. This species also occurs on the edge of forests and thickets, along streams, on rocky and scree slopes, as well as in mountain meadows. E. angustifolium prefers nutrient-rich and mesic-moist soils, but it is tolerant in terms of habitat conditions [31-33,36].

\section{PHYTOCHEMISTRY}

\section{Chemical composition}

Phytochemical studies on E. angustifolium resulted in the identification of about 250 different metabolites, of which about 170 substances have been found for the first time in this plant in the last six years $[2,3,8,42-50]$ (table 1). Polyphenols are the most abundant and are represented by flavonoids, phenolic acids, and hydrolysable tannins (ellagitannins). Other constituents such as lignans, steroids, triterpenoids, fatty acids, and essential oils, have also been identified. The structures of some bioactive compounds are given in figures 2 and 3 .

\section{Flavonoids}

About 50 different flavonoids and their derivatives have been identified in fireweed extracts. They include flavonol aglycones: kaempferol, quercetin and myricetin, which contain a single sugar moiety of glucuronic acid, rhamnose, glucose, arabinose or galactose. Quercetin-3-O-glucuronide is the most dominant and characteristic flavonoid of $E$. angustifolium, contrary to myricetin-3-O-rhamnoside (myricitrin), which is the main flavonoid of the other Epilobium species [51]. Recently, flavonol glycoconjugates acylated with hydroxycinnamic acids were also detected [50].

\section{Phenolic acids}

Phenolic acids and their derivatives are one of the dominant groups of phenolics found in E. angustifolium, and are important contributors to the antioxidant [48] and therapeutic potential against $\mathrm{BPH}$ of this species [49]. A great variety of these compounds, including 39 substances (e.g., caffeic, ellagic, ferulic, gallic, protocatechuic acids and caffeoylquinic acid isomers), has been found in the fireweed $[8,43,48-50]$.

\section{Hydrolysable tannins}

E. angustifolium contains a high level of ellagitannins, which represent about $15 \%$ of the dry mass of the herb [2]. Ellagitannins are bioactive polyphenols belonging to the class of hydrolysable tannins, characterized as hexahydroxydiphenoyl (HHDP) esters of sugar, mainly glucose. Both monomeric (e.g., tellimagrandin I, gemin D) and macrocyclic ellagitannins have been isolated from E. angustifolium herb $[2,3]$. Oenothein B is a dimer which includes two molecules of tellimagrandin I monomers. Other macrocyclic ellagitannins - oenothein A (trimer) and larger ellagitannins up to heptamers - were also detected and characterized using the UPLC-MS/MS method [2]. Oenothein B is a principal bioactive compound and the most abundant ellagitannin, whose content ranges up to $50 \%$ of the total mass of oligomeric ellagitannins in the extract [2]. Depending on the plant origin and harvest time, oenothein $\mathrm{B}$ concentration in the raw material varies from 2 to $4.5 \%[50,52,53]$. This compound has been considered to be the main contributor to the anti-androgenic, antiproliferative and anticancer, antioxidant, anti-inflammatory as well as antimicrobial effects of E. angustifolium extracts [4]. Therefore, analysis of oenothein $\mathrm{B}$ and quercetin-3-O-glucuronide contents is recommended to provide markers and a basis for the plant raw material standardization $[4,6,43,51]$.

\section{Lignans}

Recently, phytochemical analyses of ethyl acetate and $n$-butanol extracts obtained from the aerial parts of E. angustifolium resulted in the identification of five lignans, including pinoresinol and its derivatives, and salicifoliol. However, these compounds did not show the anti-BPH activity [49].

\section{Steroids, terpenoids and fatty acids}

Besides polyphenols, the aerial parts of E. angustifolium contain a lipophilic fraction rich in steroids, terpenoids and fatty acids. The presence of campesterol, cholesterol, stigmasterol as well as $\beta$-sitosterol and its derivatives was reported $[49,50,54-56]$. Fatty acids (41 identified compounds) as well as triterpenes (e.g., oleanolic, pomolic and ursolic acids) are the main components of the lipophilic fraction of E. angustifolium extracts [42]. 


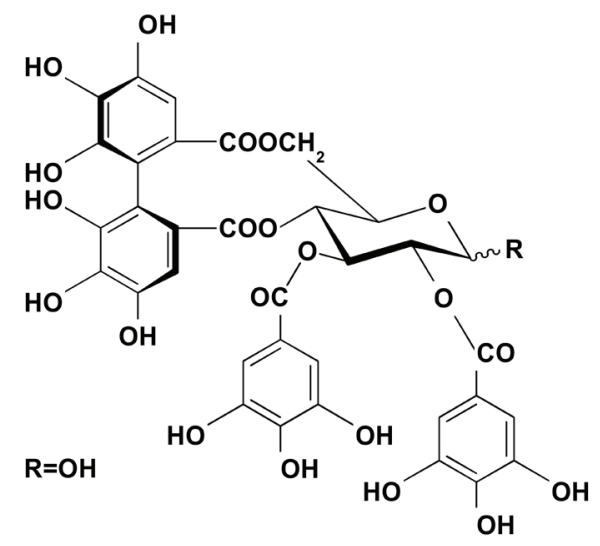

a

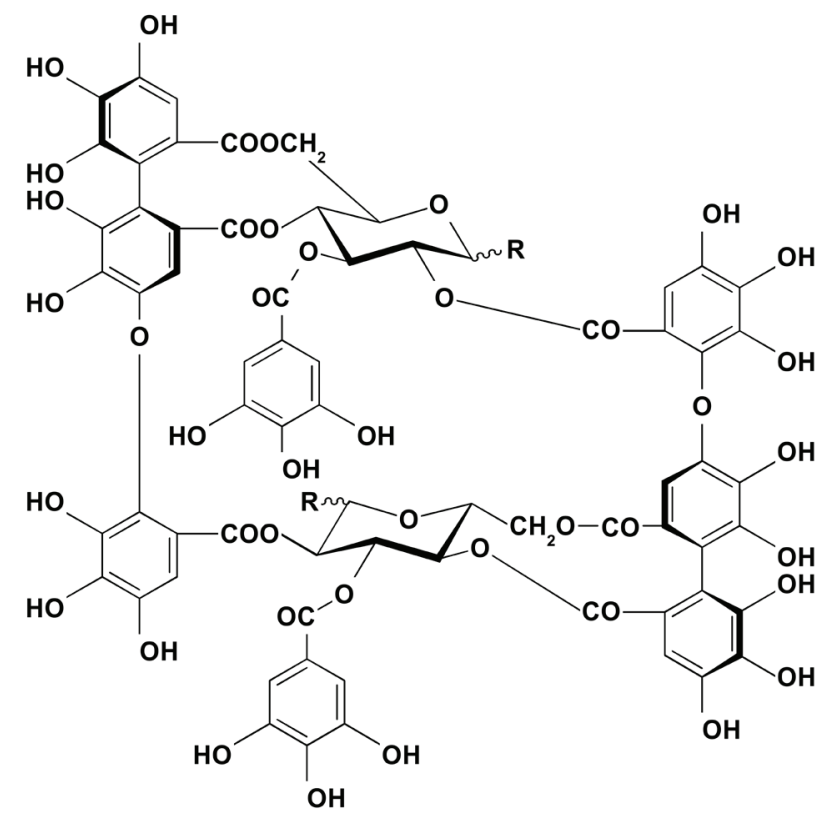

b

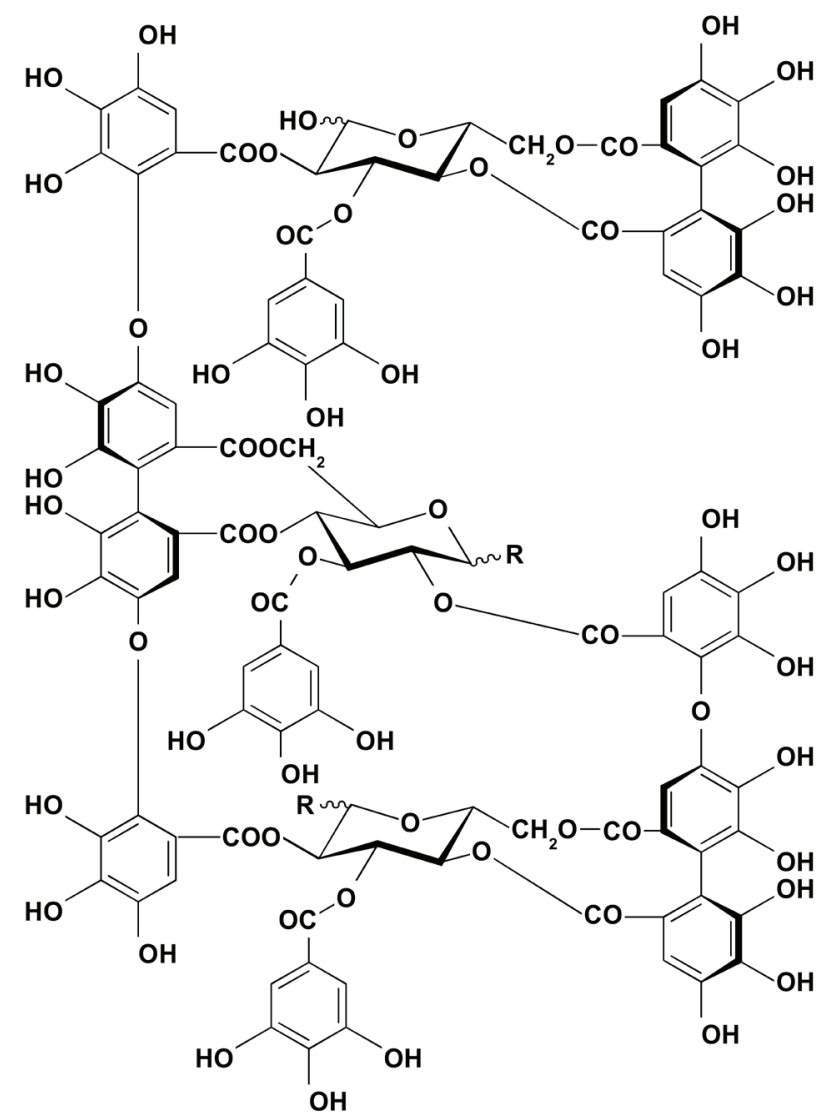

Figure 2

Chemical structures of tellimagrandin I (a), oenothein B (b), and oenothein A (c) 


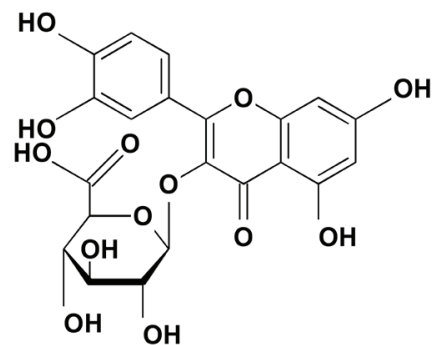

a<smiles>O=C(O)C=Cc1ccc(O)c(O)c1</smiles>

d<smiles></smiles>

b<smiles>O=c1c(OC2OCC3CC2C(O)C3O)c(-c2ccc(O)cc2)oc2cc(O)cc(O)c12</smiles>

C<smiles>O=c1oc2c(O)c(O)cc3c(=O)oc4c(O)c(O)cc1c4c23</smiles>

e<smiles>O=C(/C=C/c1ccc(O)c(O)c1)OC1CC(O)(C(=O)O)CC(O)C1O</smiles>

f<smiles>O=C(/C=C/c1ccc(O)c(O)c1)OC1CC2(O)CC(O)C(O)CC1C2</smiles>

g<smiles>CC(C)CCC[C@H](C)C12CC[C@H]3[C@H]4CC=C5CC(O)CC[C@]5(C)C4CCC3(C)[C@H]1C2</smiles><smiles>CC(C)[C@@H](C)CC[C@@H](C)C1CC[C@H]2C3CC=C4CC(O)CC[C@]4(C)C3CC[C@]12C</smiles>

h

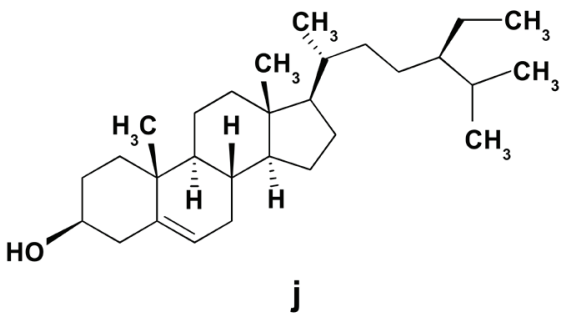

Figure 3

Chemical structures of quercetin-3-O-glucuronide (a), myricetin-3-O-rhamnoside (b), kaempherol-3-O-arabinoside (c), caffeic acid (d), ellagic acid (e), 3-O-caffeoylquinic acid (f), 5-O-caffeoylquinic acid (g), campesterol (h) cholesterol (i), and $\beta$-sitosterol (j) 
Table 1

Chemical compounds identified in Epilobium angustifolium

\begin{tabular}{|c|c|}
\hline $\begin{array}{l}\text { Group of } \\
\text { compounds }\end{array}$ & Compounds \\
\hline \multirow[t]{4}{*}{ Flavonoids } & Annulatin- $O$-arabinoside ${ }^{*}$, annulatin- $O$-glucoside ${ }^{*}$, annulatin- $O$-rhamnoside ${ }^{*}$ \\
\hline & 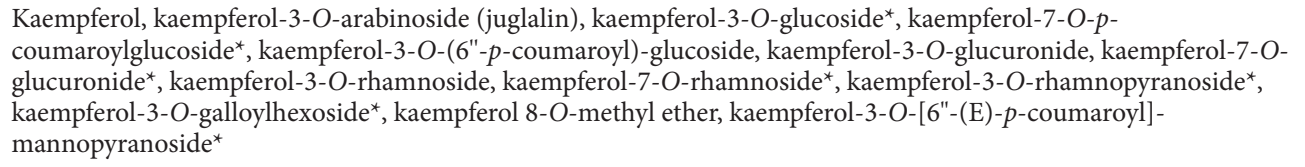 \\
\hline & 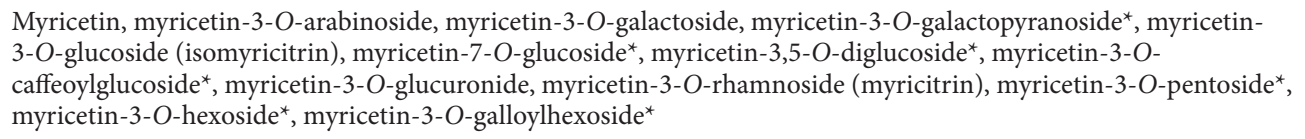 \\
\hline & 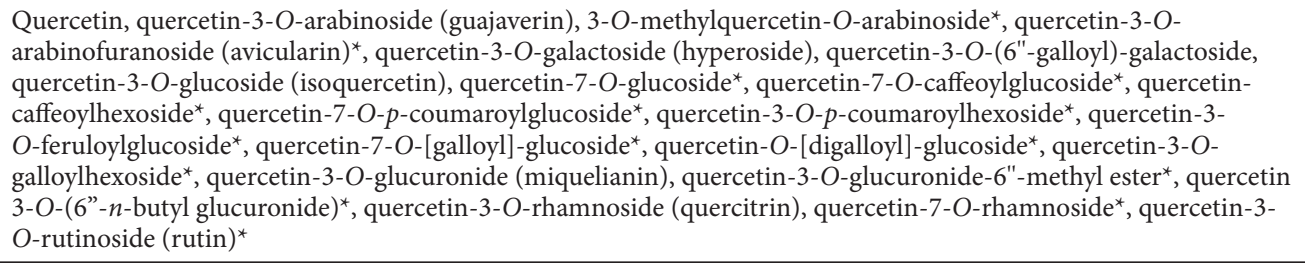 \\
\hline $\begin{array}{l}\text { Phenolic acids and } \\
\text { their derivatives }\end{array}$ & 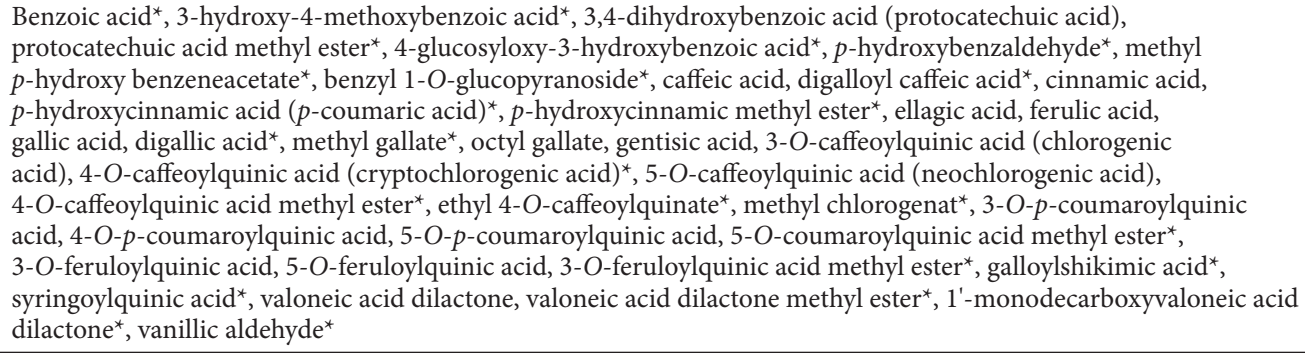 \\
\hline $\begin{array}{l}\text { Hydrolysable } \\
\text { tannins }\end{array}$ & 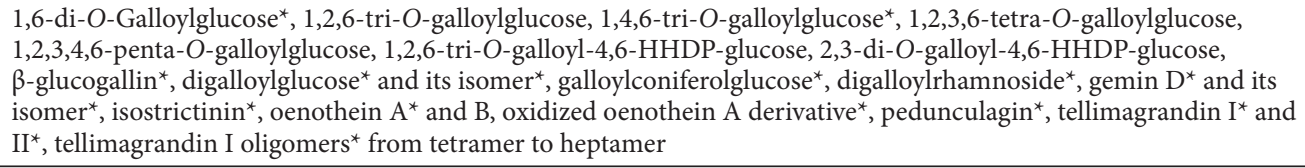 \\
\hline Lignans* & $\begin{array}{l}\text { Pinoresinol, pinoresinol-4-O-glucopyranoside, 4-ketopinoresinol, salicifoliol, } \\
(7 \mathrm{R}, 8 \mathrm{~S}) \text {-3,5'-dimethoxy-4',7-epoxy-8,3'-neolignane-5,9,9'-triol }\end{array}$ \\
\hline Steroids & $\begin{array}{l}\text { Campesterol, cholesterol, } \beta \text {-sitosterol, } \beta \text {-sitosterol caprate, } \beta \text {-sitosterol capronate, } \beta \text {-sitosterol caprylate, } \beta \text {-sitosterol } \\
\text { glucoside (daucosterol), } \beta \text {-sitosterol (6"-O-acetyl)-glucoside, } \beta \text {-sitosterol palmitate, } \beta \text {-sitosterol propionate, } \\
\text { stigmasterol }\end{array}$ \\
\hline Triterpenes & $\begin{array}{l}\text { Betulinic acid }{ }^{*} \text {, corosolic acid, maslinic acid, oleanolic acid, acetyl oleanolic acid }{ }^{*} \text {, oleanonic acid*, pomolic acid*, } \\
\text { ursolic acid, acetyl ursolic acid*, ursonic acid }{ }^{*}, \text { urs-12-ene-2a,3-diol* }\end{array}$ \\
\hline Fatty acids & 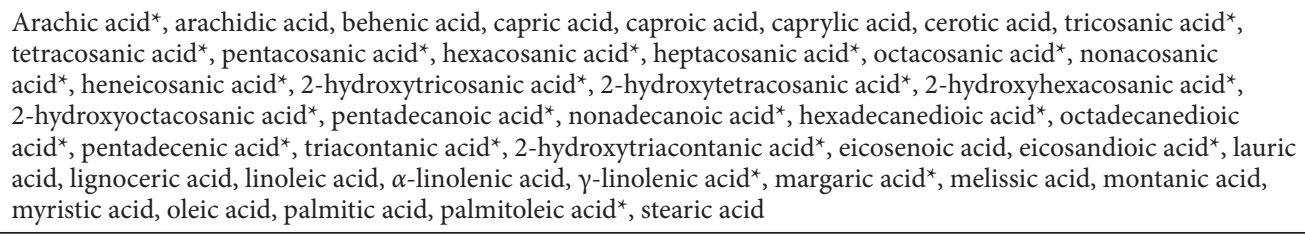 \\
\hline Essential oil ${ }^{*}$ & $\begin{array}{l}\mathcal{\varepsilon} \text {-Amorphene, anethole, cis-anethole, trans-anethole, dihydroapofarnesal, cis-arbusculone, benzyl alcohol, } \\
\beta \text {-bisabolene, } \beta \text {-bourbonene, } \gamma \text {-cadinene, } \delta \text {-cadinene, } \alpha \text {-caryophyllene, } \beta \text {-caryophyllene, } \alpha \text {-copaene, } \beta \text {-cubebene, } \\
\text { decanal, tridecane, tetradecane, } n \text {-decane, } 2,6 \text {-dimethyl-7-octen- } 4 \text {-one, } n \text {-dodecane, } \gamma \text {-elemene, estragole, eugenol, } \\
\text { trans- } \alpha \text {-farnesene, } n \text {-hexadecanol, trans-2-hexenal, cis-3-hexenol, cis-3-hexenyl hexanoate, cis-3-hexenyl pentanoate, } \\
\beta \text {-ionone, isogermacrene } \mathrm{D} \text {, isopentyl butyrate, } 3 \text {-methylbutyl-2-methylbutyrate, } 2 \text {-methyl-cis-3-hexenylbutanoate, } \\
\text { cis-3-hexenyl isobutanoate, cis-3-hexenyl butyrate, linalool, pelargol, menthol, nonanal, cis-3-hexenol propanoate, } \\
\text { cis-3-hexen-1-yl-2-methylcrotonate, phenethyl alcohol, phenylacetaldehyde, dihydromyrcenol, tetrahydrofurfuryl } \\
\text { propionate, } \gamma \text {-terpinen-7-al, vomifoliol }\end{array}$ \\
\hline Others & 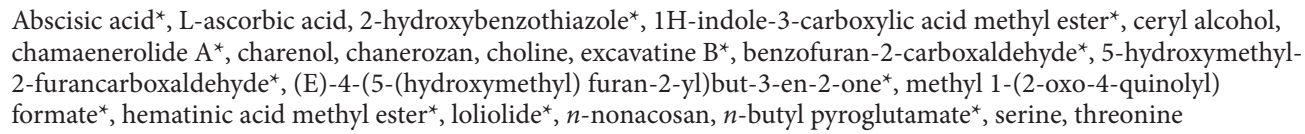 \\
\hline
\end{tabular}

* - chemical compounds identified in E. angustifolium for the first time in the last six years (2014-2019) [2, 3, 8, 42-50]. 


\section{Essential oils}

Kaškonienè et al. $[8,45]$ identified nearly 50 different compounds in essential oils of fireweed (table 1). Anethole and caryophyllenes were the most frequent constituents of the essential oil obtained from plants growing in Lithuania, and they divided specimens into two chemotypes [45].

\section{Phytochemical variability}

Fireweed is characterized by significant inter-population variability. Investigations of Kaškoniene et al. $[8,45]$ showed that the total content of phenolics and flavonoids in E. angustifolium herb harvested in the massive blooming phase from different Lithuanian populations varies from 70.6 to $144.5 \mathrm{mg} / \mathrm{g}$ and from 14.3 to $41.0 \mathrm{mg} / \mathrm{g}$, respectively. In turn, the levels of these compounds in the samples consisting of leaves and flowers, and obtained from 10 Finnish populations, were $151-206 \mathrm{mg} / \mathrm{g}$ and $5.8-16.6 \mathrm{mg} / \mathrm{g}$. Additionally, the inter-population variability was strongly expressed in the ratio of oenothein B and A as well as in flavonoid abundance, especially myricetin-3-O-glucoside and myricetin-3-O-glucuronide [3]. The phytochemical variation of E. angustifolium increases when different plant parts are analyzed, and the raw material is collected in various development phases (table 2). Generally, the highest polyphenol content was recorded in the massive flowering phase $[3,44,47,50,57]$. Flowers and inflorescences are distinguished by high amounts of flavonoids [3, 44, 47]. It was found that flavonoids and ellagitannins exhibit the most specific distribution pattern within the whole plant [3]. Flowers contained $10 \%$ more oenothein $\mathrm{B}$ and half as much oenothein A as leaves.

\section{TRADITIONAL USES}

E. angustifolium is an interesting medicinal and wild edible plant of the Northern Hemisphere. Its aerial parts (herb and leaves) have been used in European folk medicine to treat stomach disorders, liver and prostate gland inflammation as well as kidney and urinary tract diseases $[58,59]$. Traditional application of this plant in phytotherapy also includes migraine headaches, insomnia, anaemia, delirium tremens, infections, colds, etc. Externally, fireweed is used as antiphlogistic and antiseptic agent for treating mycoses, minor burns, skin rashes, ulcers, wounds as well as inflammation of the ear, nose, and throat $[4,12]$.

In the USA, usage of E. angustifolium is recommended by herbalists in the case of colic with chronic, non-inflammatory diarrhea, gastroenteritis, vomiting, dysentery, and prostatitis [60]. In Russia, fireweed tea is often consumed as a remedy for stomach ulceration, gastritis, and sleeping disorders $[61,62]$. In the 19th century, an infusion prepared from fermented leaves of E. angustifolium, called Ivan or Koporye tea, was popular in England and other Western European countries, and it constituted a very important export commodity of the Russian Empire. In turn, fireweed roots and stems are used in Chinese medicine for treatment of traumatic injury, subduing inflammation, and menstrual disorders [49].

A survey of ethnobotanical literature shows that medicinal properties of $E$. angustifolium have been well known by the North American indigenous peoples, especially in Canada and Alaska. The First Nations in northern Ontario used it to treat inflammation, burns, boils, sores, rashes, mouth ulcers, and yeast infections [63]. Among the Cree, macerated roots were applied to boils or infections, and leaves of this species were plastered on bruises. A tea from the whole plant was prepared by the Woods Cree of Saskatchewan against intestinal parasites, and crushed roots were used to boils, abscesses, and wounds. A decoction of fireweed herb was made in parts of Alaska and throughout the Arctic to initiate secretion of breast milk. In turn, the Cheyenne of Montana applied a tea from roots and leaves to rectal haemorrhage [64].

E. angustifolium has been widely utilized as a vegetable. Its young shoots, harvested in spring before blooming, were the source of the sweet and succulent raw pith or after cooking they were eaten like asparagus [30]. The unopened buds were added to salads, or pickled like capers [64], whereas the petals were used for jelly [65]. The Inuit consumed underground plant parts, after boiling [64]. In turn, the Saami occasionally collected the leaves of fireweed, mainly for mixing it with reindeer milk. In famine years, this plant has been eaten by the settlers in northern Sweden. Fireweed was also reported in the 19th century among emergency bread additives [66].

Due to the mass occurrence and blooming, E. angustifolium belongs to the important honey plants in Canada and Russia (especially Siberia). In Alaska, a sugar syrup prepared with boiled clover and fireweed blossoms is also known under the same name of fireweed honey [67]. In this 
Table 2

Phytochemical variability of Epilobium angustifolium $(\mathrm{mg} / \mathrm{g})$ in relation to the plant part and time of harvest/vegetation phase

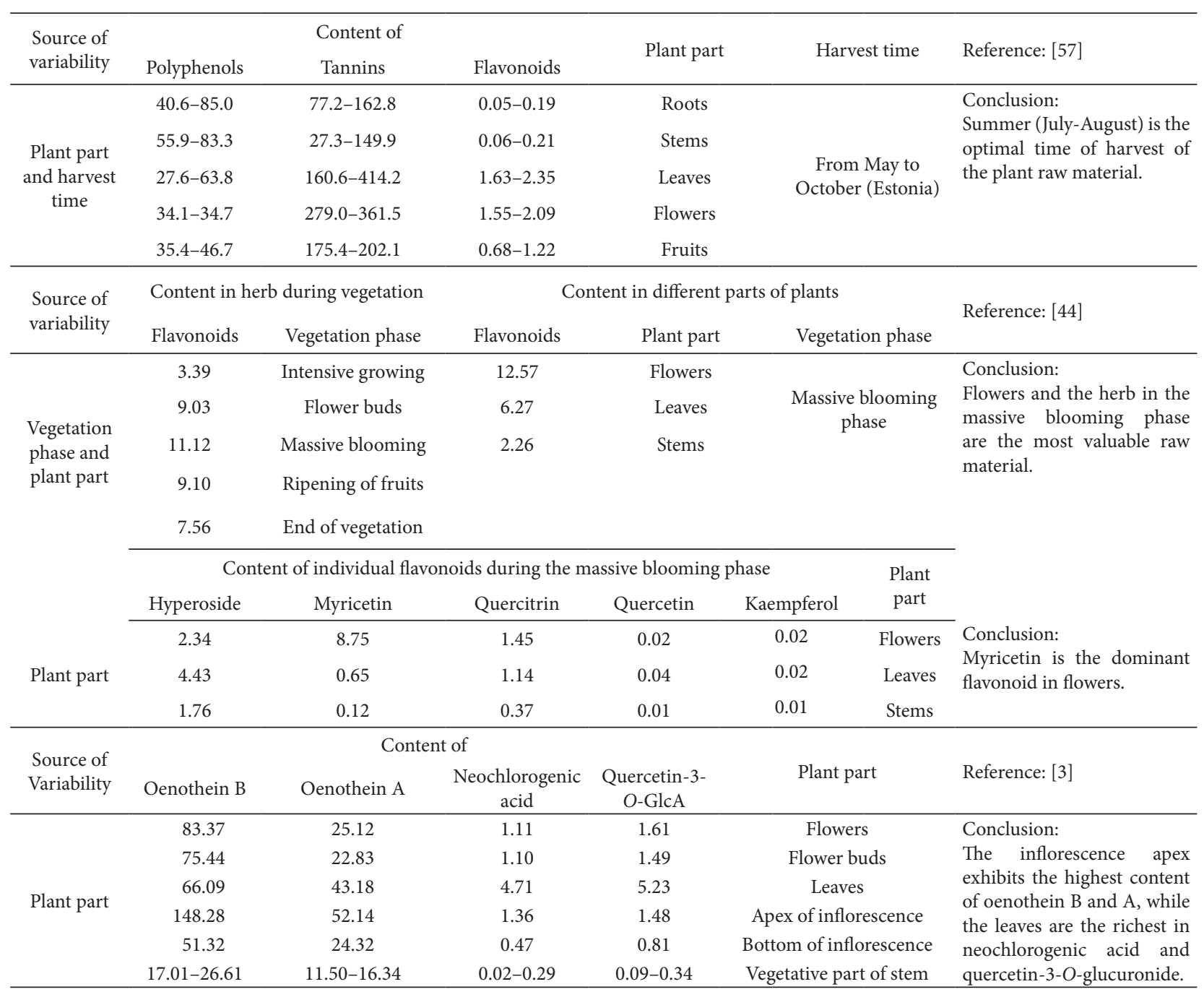

Quercetin-3-O-GlcA - quercetin-3-O-glucuronide.

region, rhubarb candy with fireweed vodka, jelly from fireweed blossoms and ice cream with its petals are made, too.

The stem fibres of E. angustifolium were used to weave of fishing nets [30]. The fresh leaves were utilized for preserving of bowstrings, whereas flowers for waterproofing of mittens and rawhide thongs [64].

Among the plants occurring in the North, E. angustifolium is one of the most attractive species. Because of its easy cultivation, large and numerous purple flowers and deep red autumn foliage, it occasionally grows as an ornamental. Fireweed was also chosen as the floral emblem of Yukon, and it is on the flag of this territory of Canada [65].

\section{CONCLUSIONS}

E. angustifolium is a valuable medicinal plant, used especially in the treatment of urogenital disorders: benign prostatic hyperplasia $(\mathrm{BPH})$ and prostatitis. In the North (Canada, Alaska, Scandinavia, and Siberia), it has been traditionally used as an edible, honey and decorative species, too. E. angustifolium is a rich source of polyphenols: flavonoids, phenolic acids and ellagitannins. Phytochemical analyses resulted in the identification of about 250 metabolites, including about 170 substances found for the first time in this plant in the last six years. Two bioactive compounds: oenothein $B$ and quercetin-3-O-glucuronide are proposed for the identification and standardization of the fireweed raw material. E. angustifolium is characterized by 
significant phytochemical variability in relation to the geographical origin, plant part and time of harvest/vegetation phase. Flowers and the herb in the massive blooming phase are the most valuable plant raw material. The inflorescence apex exhibits the highest content of oenothein $\mathrm{B}$ and $\mathrm{A}$, while the leaves are the richest in neochlorogenic acid and quercetin-3-O-glucuronide.

\section{ACKNOWLEDGEMENTS}

This work was funded by the Polish National Centre of Research and Development (grant no. PBS2/ A8/23/2013) and the Polish Ministry of Science and Higher Education (contract number 205710/E-198/ SPUB/2016/1).

Ethical approval: The conducted research is not related to either human or animal use.

Conflict of interest: Authors declare no conflict of interest.

\section{REFERENCES}

1. Allkanjari O, Vitalone A. What do we know about phytotherapy of benign prostatic hyperplasia? Life Sci J 2015; 126:42-56. doi: http://dx.doi. org/10.1016/j.lfs.2015.01.023

2. Baert N, Karonen M, Salminen JP. Isolation, characterisation and quantification of the main oligomeric macrocyclic ellagitannins in Epilobium angustifolium by ultra-high performance chromatography with diode array detection and electrospray tandem mass spectrometry. J Chromatogr A 2015; 1419:26-36. doi: http://dx.doi. org/10.1016/j.chroma.2015.09.050

3. Baert N, Kim J, Karonen M, Salminen JP. Interpopulation and inter-organ distribution of the main polyphenolic compounds of Epilobium angustifolium. Phytochemistry 2017; 134:5463. doi: http://dx.doi.org/10.1016/j.phytochem.2016.11.003

4. Schepetkin IA, Ramstead AG, Kirpotina LN, Voyich JM, Jutila MA, Quinn MT. Therapeutic potential of polyphenols from Epilobium angustifolium (fireweed). Phytother Res 2016; 30(8):1287-97. doi: http://dx.doi.org/10.1002/ptr.5648
5. Kiss A, Kowalski J, Melzig MF. Induction of neutral endopeptidase activity in PC-3 cells by an aqueous extract of Epilobium angustifolium L. and oenothein B. Phytomedicine 2006; 13(4):284-9. doi: http://dx.doi.org/10.1016/j. phymed.2004.08.002

6. Kiss AK, Bazylko A, Filipek A, Granica S, Jaszewska E, Kiarszys $U$ et al. Oenothein B's contribution to the anti-inflammatory and antioxidant activity of Epilobium sp. Phytomedicine 2011; 18(7):557-60. doi: http://dx.doi.org/10.1016/j. phymed.2010.10.016

7. Stolarczyk M, Piwowarski JP, Granica S, Stefańska J, Naruszewicz M, Kiss AK. Extracts from Epilobium sp. herbs, their components and gut microbiota metabolites of Epilobium ellagitannins, urolithins, inhibit hormone-dependent prostate cancer cells-(LNCaP) proliferation and PSA secretion. Phytother Res 2013; 27(12):1842-8. doi: http://dx.doi.org/10.1002/ptr.4941

8. Kaškonienė $V$, Stankevičius $M$, Drevinskas $T$, Akuneca I, Kaškonas P, Bimbiraitè-Survilienè K et al. Evaluation of phytochemical composition of fresh and dried raw material of introduced Chamerion angustifolium L. using chromatographic, spectrophotometric and chemometric techniques. Phytochemistry 2015; 115:18493. doi: http://dx.doi.org/10.1016/j.phytochem.2015.02.005

9. Piwowarski JP, Bobrowska-Korczak B, Stanisławska I, Bielecki W, Wrzesień R, Granica S et al. Evaluation of the effect of Epilobium angustifolium aqueous extract on LNCaP cell proliferation in in vitro and in vivo models. Planta Med 2017; 83(14-15):1159-68. doi: http://dx.doi.org/10.1055/s-0043-109372

10. Yoshida T, Yoshimura M, Amakura Y. Chemical and biological significance of oenothein $\mathrm{B}$ and related ellagitannin oligomers with macrocyclic structure. Molecules 2018; 23(3):552. doi: http:// dx.doi.org/10.3390/molecules 23030552

11. Rauha JP, Remes S, Heinonen M, Hopia A, Kähkönen M, Kujala T et al. Antimicrobial effects of Finnish plant extracts containing flavonoids and other phenolic compounds. Int J Food Microbiol 2000; 56(1):3-12. doi: http://dx.doi.org/10.1016/ S0168-1605(00)00218-X

12. Battinelli L, Tita B, Evandri MG, Mazzanti G. 
Antimicrobial activity of Epilobium spp. extracts. Farmaco 2001; 56(5-7):345-8. doi: http://dx.doi. org/10.1016/S0014-827X(01)01047-3

13. Webster D, Taschereau P, Belland RJ. Antifungal activity of medicinal plant extracts; preliminary screening studies. J Ethnopharmacol 2008; 115:140-6. doi: http://dx.doi.org/10.1016/j. jep.2007.09.014

14. Bartfay WJ, Bartfay E, Johnson JG. Gram-negative and Gram-positive antibacterial properties of the whole plant extract of willow herb (Epilobium angustifolium). Biol Res Nurs 2012; 14(1):85-9. doi: http://dx.doi.org/10.1177/1099800410393947

15. Kosalec I, Kopjar N, Kremer D. Antimicrobial activity of willowherb (Epilobium angustifolium L.) leaves and flowers. Curr Drug Targets 2013; 14(9):986-91. doi: http://dx.doi.org/10.2174/1389 4501113149990177

16. Tita B, Abdel-Haq H, Vitalone A, Mazzanti G, Saso L. Analgesic properties of Epilobium angustifolium, evaluated by the hot plate test and the writhing test. Farmaco 2001; 56(57):341-3. doi: http://dx.doi.org/10.1016/S0014827X(01)01046-1

17. Ruszová E, Cheel J, Pávek S, Moravcová M, Hermannová M, Matějková I et al. Epilobium angustifolium extract demonstrates multiple effects on dermal fibroblasts in vitro and skin photo-protection in vivo. Gen Physiol Biophys 2013; 32(3):34759. doi: http://dx.doi.org/10.4149/gpb_2013031

18. Wagner WL, Hoch PC, Raven PH. Revised classification of the Onagraceae. Syst Bot Monogr 2007; 83:1-240.

19. Kubát K, Hrouda L, Chrtek J, Kaplan Z, Kirschner J, Štěpánek J, eds. Klíč ke květeně České republiky. [Key to the flora of the Czech Republic]. Praha. Academia, 2002:436-40.

20. Rutkowski L. Klucz do oznaczania roślin naczyniowych Polski niżowej. [Key to the vascular plants of Lowland Poland]. Warsaw. PWN, 2008:323-6

21. Jäger EJ, ed. Exkursionsflora von Deutschland. Band 3. Gefäßpflanzen: Atlasband. [Flora of Germany. Vol. 3. Vascular plants: atlas]. 11th ed. Heidelberg. Elsevier Spektrum Akademischer Ver- lag, 2009:347-51.

22. The Plant List. Epilobium angustifolium L. 2013. http://theplantlist.org/tpll.1/record/kew2790112. Accessed 12 July 2019.

23. Holub J. Taxonomic and nomenclatural remarks on Chamaenerion auct. Folia Geobot Phytotaxon 1972; 7:81-90.

24. Chen C-J, Hoch PC, Raven PH. Systematics of Epilobium (Onagraceae) in China. Syst Bot Monogr 1992; 34:1-209. doi: http://dx.doi. org/10.2307/25027806

25. Sennikov AN. Chamerion or Chamaenerion (Onagraceae)? The old story in new words. Taxon 2011; 60(5):1485-8.

26. Baum DA, Sytsma KJ, Hoch PC. A phylogenetic analysis of Epilobium (Onagraceae) based on nuclear ribosomal DNA sequences. Syst Bot 1994; 19(3):363-88. doi: http://dx.doi. org/10.2307/2419763

27. Levin RA, Wagner WL, Hoch PC, Nepokroeff M, Pires JC, Zimmer EA et al. Family-level relationships of Onagraceae based on chloroplast $r b c L$ and $n d h F$ data. Am J Bot 2003; 90(1):107-15. doi: http://dx.doi.org/10.3732/ajb.90.1.107

28. Levin RA, Wagner WL, Hoch PC, Hahn WJ, Rodriguez A, Baum DA et al. Paraphyly in tribe Onagreae: Insights into phylogenetic relationships of Onagraceae based on nuclear and chloroplast sequence data. Syst Bot 2004; 29(1):147-64. doi: http://dx.doi.org/10.1600/036364404772974293

29. Nowick E. Historical common names of Great Plains Plants, with Scientific Names Index. Volume II: Scientific Names Index. Lincoln. Zea EBooks, 2015:1-452.

30. Fleenor R. Plant Guide for Fireweed (Chamerion angustifolium). Spokane. USDA-Natural Resources Conservation Service, 2016:1-5.

31. Tacik T. Rząd: Myrtales, Mirtowce. [Order: Myrtales]. In: Szafer W, Pawłowski B, eds. Flora Polska. Rośliny naczyniowe Polski i ziem ościennych. Tom VIII [Flora of Poland. Vascular plants of Poland and neighboring lands. Vol. 8], Warsaw. PWN, 1959:184-269. 
32. Myerscough PJ. Biological flora of the British Isles. Epilobium angustifolium L (Chamaenerion angustifolium (L) Scop). J Ecol 1980; 68:1047-74.

33. Broderick DH. The biology of Canadian weeds. 93. Epilobium angustifolium L. (Onagraceae). Can J Plant Sci 1990; 70(1):247-59. doi: http://dx.doi. org/10.4141/cjps90-027

34. Wiese JL, Meadow JF, Lapp JA. Seed weights for northern Rocky Mountain native plants with an emphasis on Glacier National Park. Native Plants J 2012; 13:39-49. doi: http://dx.doi.org/10.3368/ npj.13.1.39

35. Buchwald W, Kozłowski J, Szczyglewska D, Forycka A. Biology of germination of medicinal plant seeds. Part XXII: Seeds of Chamaenerion angustifolium (L.) Scop. from Oenotheraceae family. Herba Pol 2006; 52:16-21.

36. Mosquin T. A new taxonomy for Epilobium angustifolium L. (Onagraceae). Brittonia 1966; 18:167-88.

37. Chen C-J, Hoch PC, Raven PH, Boufford DE, Wagner WL. Onagraceae. Flora of China. Beijing. Science Press, 2007:400-27.

38. Martin SL, Husband BC. Adaptation of diploid and tetraploid Chamerion angustifolium to elevation but not local environment. Evolution 2013; 67:1780-91. doi: http://dx.doi.org/10.1111/ evo.12065

39. Thompson KA, Husband BC, Maherali H. Climatic niche differences between diploid and tetraploid cytotypes of Chamerion angustifolium (Onagraceae). Am J Bot 2014; 101:1868-75. doi: http://dx.doi.org/10.3732/ajb.1400184

40. Husband BC, Schemske DW. Cytotype distribution at a diploid-tetraploid contact zone in Chamerion (Epilobium) angustifolium (Onagraceae). Am J Bot 1998; 85(12):1688-94. doi: http://dx.doi. org/10.2307/2446502

41. Guo W, Yang J, Sun X-D, Chen G-J, Yang Y-P, Duan Y-W. Divergence in eco-physiological responses to drought mirrors the distinct distribution of Chamerion angustifolium cytotypes in the Himalaya-Hengduan Mountains region. Front Plant Sci 2016; 7:1329. doi: http://dx.doi. org/10.3389/fpls.2016.01329
42. Frolova TS, Sal'nikova OI, Dudareva TA, Kukina TP, Sinitsyna OI. Isolation of pomolic acid from Chamaenerion angustifolium and the evaluation of its potential genotoxicity in bacterial test systems. Russ J Bioorganic Chem 2014; 40(1):82-8. doi: http://dx.doi.org/10.1134/S1068162013060046

43. Granica S, Piwowarski JP, Czerwińska ME, Kiss AK. Phytochemistry, pharmacology and traditional uses of different Epilobium species (Onagraceae): A review. J Ethnopharmacol 2014; 156:316-46. doi: http://dx.doi.org/10.1016/j. jep.2014.08.036

44. Maruška A, Ragažinskienė $O$, Vyšniauskas $O$, Kaškonienė V, Bartkuvienė $\mathrm{V}$, Kornyšova $\mathrm{O}$ et al. Flavonoids of willow herb (Chamerion angustifolium (L.) Holub) and their radical scavenging activity during vegetation. Adv Med Sci 2014; 59(1):136-41. doi: http://dx.doi.org/10.1016/j.advms.2013.10.002

45. Kaškonienė V, Maruška A, Akuņeca I, Stankevičius M, Ragažinskienė $\mathrm{O}$, Bartkuvienė V et al. Screening of antioxidant activity and volatile compounds composition of Chamerion angustifolium (L.) Holub ecotypes grown in Lithuania. Nat Prod Res 2016; 30(12):1373-81. doi: http:// dx.doi.org/10.1080/14786419.2015.1058792

46. Moilanen J, Koskinen P, Salminen JP. Distribution and content of ellagitannins in Finnish plant species. Phytochemistry 2015; 116:188-97. doi: http:// dx.doi.org/10.1016/j.phytochem.2015.03.002

47. Monschein M, Jaindl K, Buzimkić S, Bucar F. Content of phenolic compounds in wild populations of Epilobium angustifolium growing at different altitudes. Pharm Biol 2015; 53(11):157682. doi: http://dx.doi.org/10.3109/13880209.201 4.993039

48. Deng LQ, Zhou SY, Mao JX, Liu S, Lan XZ, Liao $\mathrm{ZH}$ et al. HPLC-ESI-MS/MS analysis of phenolics and in vitro antioxidant activity of Epilobium angustifolium L. Nat Prod Res 2018; 32(12):14325. doi: http://dx.doi.org/10.1080/14786419.2017. 1344659

49. Deng L, Zong W, Tao X, Liu S, Feng Z, Lin Y et al. Evaluation of the therapeutic effect against benign prostatic hyperplasia and the active constituents from Epilobium angustifolium L. J Ethnopharmacol 2019; 232:1-10. doi: http://dx.doi. 
org/10.1016/j.jep.2018.11.045

50. Gryszczyńska A, Dreger M, Piasecka A, Kachlicki P, Witaszak N, Sawikowska A et al. Qualitative and quantitative analyses of bioactive compounds from ex vitro Chamaenerion angustifolium (L.) (Epilobium angustifolium) herb in different harvest times. Ind Crops Prod 2018; 123:208-20. doi: http://dx.doi.org/10.1016/j.indcrop.2018.06.010

51. Hevesi TB, Blazics B, Kéry Á. Polyphenol composition and antioxidant capacity of Epilobium species. J Pharm Biomed Anal 2009; 49(1):26-31. doi: http://dx.doi.org/10.1016/j.jpba.2008.09.047

52. Ducrey B, Marston A, Göhring S, Hartmann RW, Hostettmann K. Inhibition of $5 \alpha$-reductase and aromatase by the ellagitannins oenothein $\mathrm{A}$ and oenothein B from Epilobium species. Planta Med 1997; 63(2):111-4. doi: http://dx.doi. org/10.1055/s-2006-957624

53. Granica S, Bazylko A, Kiss AK. Determination of macrocyclic ellagitannin oenothein B in plant materials by HPLC-DAD-MS: method development and validation. Phytochem Anal 2012; 23(6):5827. doi: http://dx.doi.org/10.1002/pca.2358

54. Hiermann A, Mayr K. The investigation of active compounds from Epilobium species. The occurrence of sitosterol derivatives in Epilobium angustifolium L. and Epilobium parviflorum Schreb. Sci Pharm 1985; 53:39-44.

55. Nowak R, Krzaczek T. Sterole w zielu Epilobium angustifolium L. [Sterols in the herb of Epilobium angustifolium L.]. Herba Pol 1998; 44(4):297-9.

56. Węglarz Z, Kosakowska O, Pelc M, Geszprych A, Przybył JL, Bączek K. Intraspecific variability of fireweed (Chamaenerion angustifolium /L./ Scop.) and evening primrose (Oenothera biennis L.) in respect of sterol content. Herba Pol 2011; 57(2):7-15.

57. Jürgenson S, Matto V, Raal A. Vegetational variation of phenolic compounds in Epilobium angustifolium. Nat Prod Res 2012; 26(20):1951-3. doi: http://dx.doi.org/10.1080/14786419.2011.643310

58. Redžić SS. The ecological aspect of ethnobotany and ethnopharmacology of population in Bosnia and Herzegovina. Coll Antropol 2007; 31(3):869-90.

59. Vogl S, Picker P, Mihaly-Bison J, Fakhrudin N,
Atanasov AG, Heiss EH et al. Ethnopharmacological in vitro studies on Austria's folk medicine - An unexplored lore in vitro anti-inflammatory activities of 71 Austrian traditional herbal drugs. J Ethnopharmacol 2013; 149:750-71. doi: http:// dx.doi.org/10.1016/j.jep.2013.06.007

60. Moore M. Specific indications for herbs in general use. 3rd ed. Bisbee. Southwest School of botanical Medicine, 1997:1-58. http://www.swsbm. com/ManualsMM/SpecIndic3.pdf. Accessed 12 July 2019.

61. Shikov AN, Poltanov EA, Dorman HJD, Makarov VG, Tikhonov VP, Hiltunen R. Chemical composition and in vitro antioxidant evaluation of commercial water-soluble willow herb (Epilobium angustifolium L.) extracts. J Agric Food Chem 2006; 54(10):3617-24. doi: http://dx.doi.org/10.1021/ jf052606i

62. Galambosi B, Galambosi Z, Shikov AN, Kosman VM, Pozharitskaya ON, Kauppinen Set al. Optimization of the fermentation of fireweed (Epilobium angustifolium) shoot. In: Kauppinen S, Galambosi B, eds. Fireweed, roseroot, bergenia and chokeberry - joint research for supporting the herb production. Nat Res Bioeconomy Stud 2016; 72:11-22. http://urn.fi/URN:ISBN:978-952-326-338-3. Accessed 12 July 2019.

63. Hassan HM, Jiang Z-H, Syed TA, Qin W. Review: Northern Ontario medicinal plants. Can J Plant Sci 2012; 92(5):815-28. doi: http://dx.doi. org/10.4141/cjps2012-006

64. Rogers RD. Fireweed - a treasured medicine of the boreal forest. Discov Phytomed 2014; 1:10-5. doi: http://dx.doi.org/10.15562/phytomedicine.2014.16

65. Small E, Catling PM. Canadian medicinal crops. Ottawa. NRC Research Press, 1999:1-240.

66. Svanberg I. The use of wild plants as food in pre-industrial Sweden. Acta Soc Bot Pol 2012; 81(4):31727. doi: http://dx.doi.org/10.5586/asbp.2012.039

67. Petersen S, Bryant VM. Fireweed - a premier (but fickle) honey plant. Am Bee J 2010; 150(4):395-8. 